\title{
Improvement of Productivity of the Moderate Metabolism Clone GT 1 of Hevea Brasiliensis Muell. Arg. by Early Upward Tapping in Côte d'Ivoire
}

\author{
Obouayeba Samuel ${ }^{1, *}$, Soumahin Eric Francis ${ }^{2}$, Lacote Regis ${ }^{3}$, Essehi Jean Lopez ${ }^{1}$, Gohet Eric ${ }^{3}$, \\ Obouayeba Abba Pacome ${ }^{2}$ \\ ${ }^{1}$ Centre National de Recherche Agronomique (CNRA), Bimbresso Research Station, Hevea Programme, Abidjan, Côte d'Ivoire \\ ${ }^{2}$ Laboratory of Plant Physiology and Pathology, Agroforestry Training and Research Unit, Jean Lorougnon Guédé University, Daloa, Côte \\ d'Ivoire \\ ${ }^{3}$ Centre for International Cooperation in Agricultural Research for Development (CIRAD), Own research unit (PRU), Tree Crop-Based \\ Systems, Montpellier, France
}

\section{Email address: \\ obouayeba12samuel@yahoo.com (O. Samuel) \\ ${ }^{*}$ Corresponding author}

\section{To cite this article:}

Obouayeba Samuel, Soumahin Eric Francis, Regis Lacote, Essehi Jean Lopez, Eric Gohet, Obouayeba Abba Pacome. Improvement of Productivity of the Moderate Metabolism Clone GT 1 of Hevea Brasiliensis Muell. Arg. by Early Upward Tapping in Côte d'Ivoire. American Journal of BioScience. Vol. 9, No. 1, 2021, pp. 25-33. doi: 10.11648/j.ajbio.20210901.14

Received: January 23, 2021; Accepted: February 1, 2021; Published: February 10, 2021

\begin{abstract}
The quest for greater return on investment at short time is a recurring concern of the rubber industry. Early reverse tapping could be an option to this concern. It is therefore to verify this hypothesis that five different stages of initiation of upward tapping, $6^{\text {th }}, 7^{\text {th }}, 8^{\text {th }}, 9^{\text {th }}$ year and the control in $10^{\text {th }}$ year, with application of 2.5 and $5 \%$ ethephon was conducted for eight years in the South-East (Bettié) and the Centre-West (Gagnoa) of Côte d'Ivoire. Irrespective of the ethephon

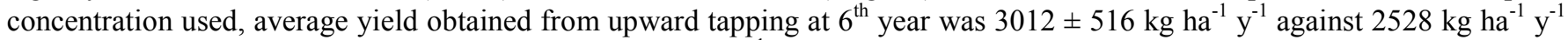
in the control, where controlled upward tapping started at $10^{\text {th }}$ year with a productivity gain of $19 \%$. The mean annual increase in circumference in the upward tapped trees at $6^{\text {th }}$ year, was $3.02 \pm 0.18 \mathrm{~cm} \mathrm{y}^{-1}$ and statistically higher than that of the control treatment $\left(2.40 \mathrm{~cm} \mathrm{y}^{-1}\right)$. Physiological profiles improved during the experiment, regardless of site and of periods of upward tapping. Generally, the sensitivity to panel dryness in the control is more pronounced than that of early upward tapping. Our results suggest very early upward tapping at $6^{\text {th }}$ year after the 5 years of downward tapping, is the best period to harvest latex from the high tapping panel.
\end{abstract}

Keywords: Early Upward Tapping, Rubber Productivity, Radial Vegetative Growth, Physiological Profile, Panel Dryness Sensitivity

\section{Introduction}

In the natural rubber growing region of Africa, the management of rubber plantation is carried out according to the tapping panel management standard scheme [1]. It consists of latex harvesting on the downward panels (BO) and upward panels (HO). Downward tapping is by far the most used and is practiced, in most cases, over the first nine years of tapping, followed by upward tapping, which does not take place until the tenth year of operation. This scheme was used for more than 40 years in agro-industrial plantations and introduced to smallholder's plantations, after been successfully tested since 2000 [2]. Despite its efficiency and high utilization, the current trend is to improve rubber productivity in order to increase revenues. Also, the producers prefer latex harvesting systems yielding a greater return on investment in a shorter time period. From this point of view, it is conceivable to propose a tapping itinerary shortening the tapping period. However, the rubber productivity performance of upward tapping is well known and upward tapping is much more productive with an output 
at least $25 \%$ higher than downward tapping [2]. The perspective of reducing the downward tapping is conceivable and downward tapping for four years was sufficient to practice upward tapping from the $5^{\text {th }}$ year the onwards [3, 4]. However, the study indicated that the tapping treatment of four of downward half-spiral followed by upward half-spiral showed a high rate of TPD. This revealed that most productive systems, especially the earliest applied upward tapping, further weaken the rubber trees $[5,6]$ and exacerbate their sensitivity to TPD. The feasibility of upward tapping from the fourth year of semi-spiral downward tapping (early upward tapping relative to the current tapping panel management standard; [1]), is investigated by reducing the bark panel length to quarter of a spiral to avoid overexploitation of trees [7]. To achieve this upward tapping after increasing periods of downward tapping was conducted at two sites in South-East and Central-West of Côte d'Ivoire, for eight years. This communication reports the results of the study on the feasibility of early upward tapping and defines the best stage to initiate upward tapping.

\section{Experimental}

\subsection{Plant Material}

Clone GT 1 of Hevea brasiliensis belonging to the moderate metabolic activity class was utilised for this study. Its growth is moderate before tapping starts [8, 9]. Homogeneity of GT 1 plantations compensate the low yield resulted due to low productivity level of trees. This clone shows an average sensitivity to tapping panel dryness and resistance to breakage due to wind. Except for low inorganic phosphorus content, which reflects an average metabolism, its physiological characteristics are all favourable to the production of rubber.

\subsection{Experimental Design}

The experiment, conducted in smallholder's plantations during eight years (from October 2006 to October 2014), was carried out in Gagnoa (Central-West) and Bettié (South-East) of Côte d'Ivoire. Average temperature was $26.3^{\circ} \mathrm{C}$ at Bettié and $26.2^{\circ} \mathrm{C}$ at Gagnoa. Average rainfall was $1300 \mathrm{~mm}$ and $1384 \mathrm{~mm}$, respectively at Bettié and Gagnoa [10, 11]. At Bettié, as well as, Gagnoa, soils are highly desaturated and gravelly ferralitic [12]. Fisher's experimental blocking design included 9 treatments and 4 replicates were used for the experiment. At Bettié, the planting density was 555 trees per hectare $(6 \mathrm{~m} \times 3 \mathrm{~m})$ and it was $4.75 \mathrm{~m} \times 4.75 \mathrm{~m}$ at Gagnoa with an initial density of 443 trees per hectare. Both fields were planted in 1994 and tapping started in 2000 to 2001 . At the start of this study, the trees were in the $5^{\text {th }}$ year of downward tapping on panel A. The choice of these parcels and trees was made on the basis of:

1) the homogeneity of their circumference $(\geq 55 \mathrm{~cm})$, after elimination of the border trees;

2) the homogeneity of their unstimulated production (yield) tree by tree, in anterior downward tapping, carried out with 2 to 3 coagulum corresponding to the number of tapping, after study of the physiological parameters of the latex;

3 ) the homogeneity of the history of downward tapping since 5 years;

4) density of trees tapping $\geq 400 \mathrm{ha}^{-1}$

5) the opening or tapping was done at a height of $1.40 \mathrm{~m}$ from the ground, for upward tapping treatments in accordance with the established protocol.

The plots consisted of 20 trees selected on the basis of their uniformity of circumference and productivity.

\subsection{Treatments}

The trial started in the sixth year (2006-2007) and ended in year $13^{\text {th }}(2013-2014)$, i.e. 8 years. A total of nine treatments (A, B, C, D, E, F, G, H and J or control) were used. The trees were stimulated on the tapping panel by applying $1 \mathrm{~g}$ of ethrel paste per tree, as a $1 \mathrm{~cm}$ wide strip [13]. The stimulating paste used was obtained by mixing Ethrel and palm oil. Ethrel contains 2.5 or 5\% of active ingredient (m.a) which is chloro-2-ethyl phosphonic acid or ethephon. The stimulation frequencies were 6 to 13 per year $\left(6-13 \mathrm{y}^{-1}\right)$ according to the treatments:

A: Upward tapping at $6^{\text {th }}$ year (Downward tapping up to $5^{\text {th }}$ year), ET 5\% Pal(1) $13 \mathrm{y}^{-1}$

B: Upward tapping at $6^{\text {th }}$ year (Downward tapping up to $5^{\text {th }}$ year), ET 2.5\% Pa1(1) 6-13 y ${ }^{-1}$

1) $1^{\text {st }}$ year of upward tapping ET $2.5 \% \operatorname{Pa} 1(1) 6 y^{-1}$

2) $2^{\text {nd }}$ year of upward tapping ET $2.5 \% \mathrm{~Pa} 1(1) 8 \mathrm{y}^{-1}$

3) $3^{\text {rd }}$ year of upward tapping ET $2.5 \% \mathrm{~Pa} 1(1) 10 \mathrm{y}^{-1}$

4) $4^{\text {th }}$ year of upward tapping ET $2.5 \% \mathrm{~Pa} 1(1) 12 \mathrm{y}^{-1}$

5) $5^{\text {th }}$ year of upward tapping and after ET 5\% Pal(1) $13 \mathrm{y}^{-1}$

C: Upward tapping at $7^{\text {th }}$ year (Downward tapping up to $6^{\text {th }}$ year), ET 5\% Pa1(1) $13 \mathrm{y}^{-1}$

D: Upward tapping at $7^{\text {th }}$ year (Downward tapping up to $6^{\text {th }}$ year), ET 2.5\% Pal(1) 6-13 $\mathrm{y}^{-1}$

1) $1^{\text {rst }}$ year of upward tapping ET $2.5 \% \operatorname{Pa} 1(1) 6 y^{-1}$

2) $2^{\text {nd }}$ year of upward tapping ET $2.5 \% \operatorname{Pa} 1(1) 8 \mathrm{y}^{-1}$

3) $3^{\text {rd }}$ year of upward tapping ET $2.5 \%$ Pa1(1) $10 y^{-1}$

4) $4^{\text {th }}$ year of upward tapping and after ET 5\% Pa1(1) $13 y^{-1}$

E: Upward tapping at $8^{\text {th }}$ year (Downward tapping up to $7^{\text {th }}$ year), ET Pa1(1) $11 \mathrm{y}^{-1}$

F: Upward tapping at $8^{\text {th }}$ year (Downward tapping up to $7^{\text {th }}$ year), ET 2.5\% Pa1(1) $8-13 \mathrm{y}^{-1}$

1) $1^{\text {rst }}$ year of upward tapping ET $2.5 \%$ Pa1(1) $8 y^{-1}$

2) $2^{\text {nd }}$ year of upward tapping ET $2.5 \% \mathrm{~Pa}(1) 10 \mathrm{y}^{-1}$

3) $3^{\text {rd }}$ year of upward tapping and after ET 5\% Pa1(1) $13 y^{-1}$

G: Upward tapping at $9^{\text {th }}$ year (Downward tapping up to $8^{\text {th }}$ year), ET Pa1(1) $11 \mathrm{y}^{-1}$

$\mathrm{H}$ : Upward tapping at $9^{\text {th }}$ year (Downward tapping up to $8^{\text {th }}$ year), ET 2.5\% Pa1(1) 6-11 $\mathrm{y}^{-1}$

1) $1^{\text {rst }}$ year of upward tapping ET $2.5 \% \operatorname{Pa} 1(1) 10 y^{-1}$

2) $2^{\text {nd }}$ year of upward tapping and after ET 5\% Pa1(1) $13 y^{-1}$

$\mathrm{J}$ : Control, classic upward tapping at $10^{\text {th }}$ year (downward tapping up to $9^{\text {th }}$ year), ET Pa1(1) $11 \mathrm{y}^{-1}$

The scheme of panel tapping of the various treatments tested is illustrated in the Figures 1, 2, 3, 4 and 5. 


\subsection{Measurement of Rubber Yield}

Rubber yield under each treatment was weighed every 4 weeks using a scale [4]. Samples of fresh rubber were collected for each treatment to determine the Coefficient of Transformation (CT), which is the percentage of dry matter in a given rubber sample, which was used to calculate the production of dry rubber expressed in grams per tree per tapping $\left(\mathrm{g} \mathrm{t}^{-1} \mathrm{t}^{-1}\right)$ and in kilograms per hectare per year $\left(\mathrm{kg} \mathrm{ha}^{-1} \mathrm{y}^{-1}\right)$.

\subsection{Measurement Radial Vegetative Growth}

Vegetative growth in terms of the thickness of the rubber tree trunk was assessed from circumference measurements at $1.70 \mathrm{~m}$ above the ground, using a measuring tape. These measurements were made at the start of the trial and then, once a year, during the last quarter of the period of normal metabolic activity of the rubber trees (October to December). Indeed, this period just before the onset of natural defoliation (January to February), coincides with a very low growth of rubber trees.

The girth increment $\left(\mathrm{G}_{\mathrm{i}}\right)$ was determined by the following relation:

$$
\mathrm{G}_{\mathrm{i}}\left(\mathrm{cm} \text { year }^{-1}\right)=\mathrm{G}_{\mathrm{n}}-\mathrm{G}_{\mathrm{n}-1} \text {. }
$$

Where $\mathrm{Gn}$ is the mean girth of trees in the year $\mathrm{n}$ and $\mathrm{Gn}_{-1}$, the mean girth of trees in the year n-1.

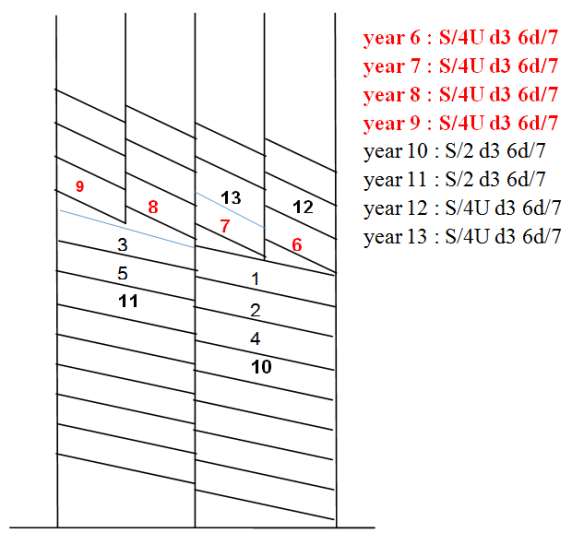

Figure 1. Treatments $A$ and $B$.

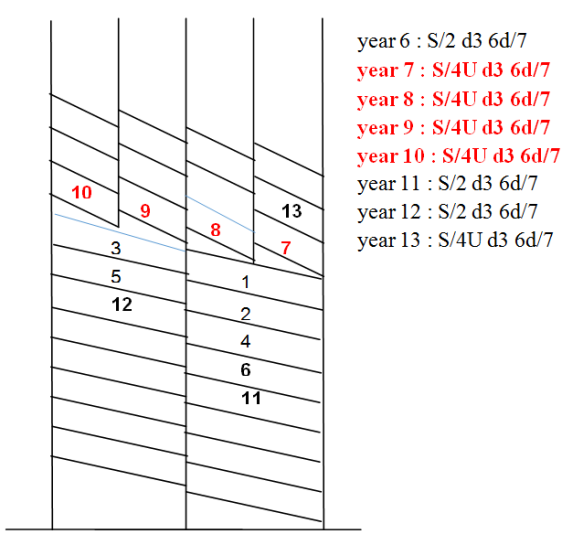

Figure 2. Treatments $C$ and $D$.

NB. The years highlighted in red are those corresponding to the early upward tapping.

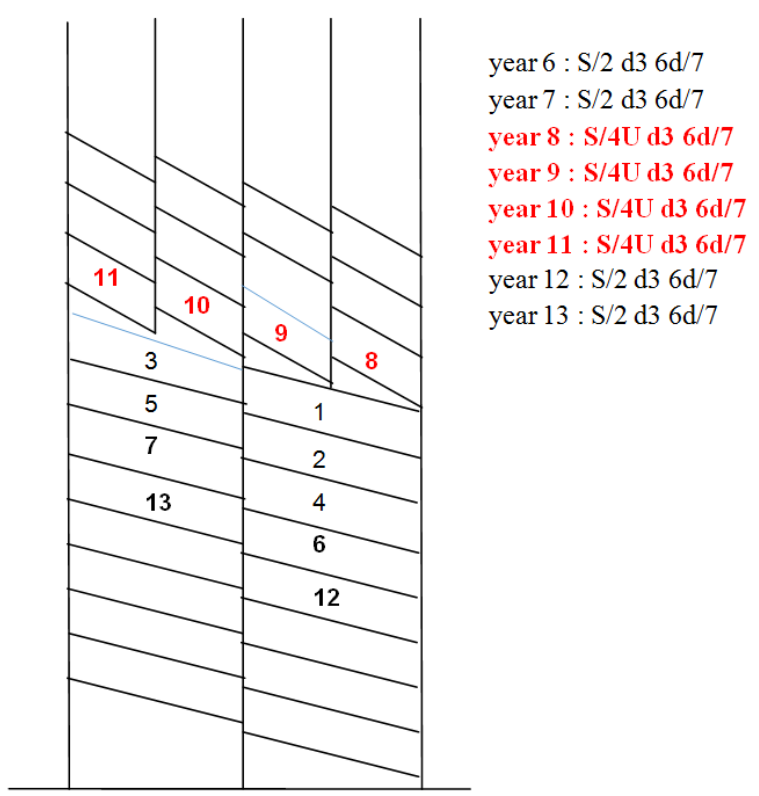

Figure 3. Treatments $E$ and $F$.

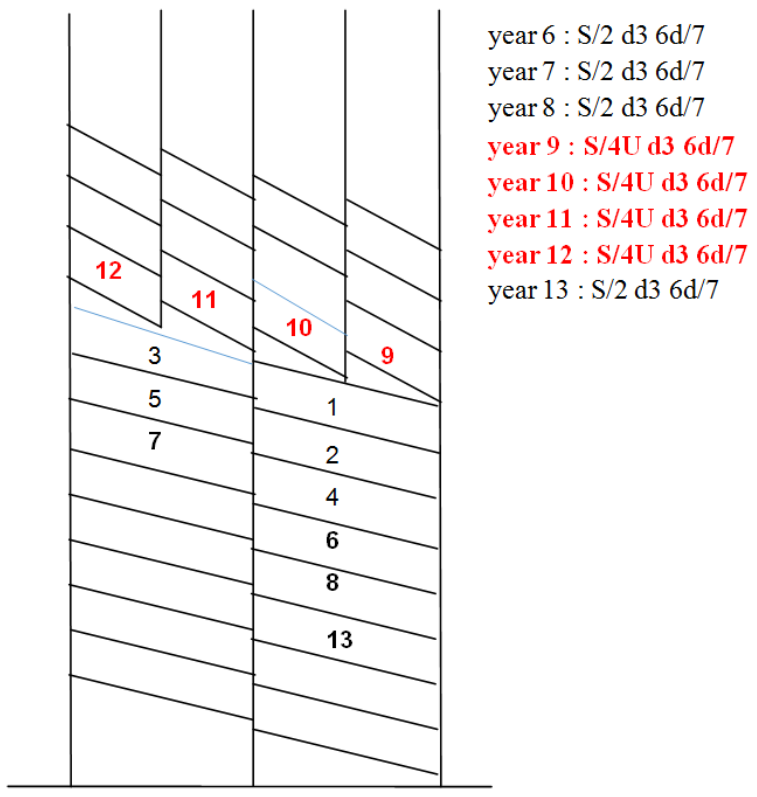

Figure 4. Treatments $G$ and $H$.

NB. The years highlighted in bold are those corresponding to the conventional upward tapping.

\subsection{Measurement of Dry Rubber Content}

The dry rubber content (DRC) was determined by weighing a sample of $1 \mathrm{ml}$ of latex before and after drying in oven at $80^{\circ} \mathrm{C}$ for $24 \mathrm{~h}$ using the following formula:

$$
\operatorname{DRC}(\%)=\text { D.W. } \times \text { F.W. }{ }^{-1} \times 100
$$

D.W.: Weight of dry latex;

F.W.: Weight of fresh latex.

\subsection{Physiological Parameters}

Sucrose, inorganic phosphorus and reduced thiol groups 
were measured out on the clear serum called serum-TCA (trichloroacetic acid), obtained after acid coagulation of latex (harvested from the trees selected in the elementary plot). 1 $\mathrm{ml}$ of latex was added to $9 \mathrm{ml} 2.5 \%$ TCA. The serum contained in the coagulated rubber was expressed using a glass rod. The serum obtained was then filtered with glass wool to eliminate the bulk of impurities, such as rubber particles remaining in suspension. The results were expressed in millimoles per litre of latex $\left(\mathrm{mmol}^{-1}\right)$ from the coefficients of the calibration ranges.

Sucrose content: Sucrose was measured by the Ashwell anthrone method. In the presence of concentrated acid, hexoses are dehydrated to give furfural which reacts with anthrone giving a blue-green color. A volume of $100 \mu \mathrm{l}$ of serum was added to $400 \mu \mathrm{l}$ of $2.5 \% \mathrm{TCA}$ and $3 \mathrm{ml}$ of anthrone reagent was added. The solution was immersed in a double boiler for $5 \mathrm{~min}$. After cooling, absorbance was read at a wavelength of $627 \mathrm{~nm}$ and compared to the control $(0.5 \mathrm{ml}$ of $2.5 \% \mathrm{TCA}+3 \mathrm{ml}$ of anthrone reagent $)$. Sucrose represents almost all the sugar of the latex and the sugar content was expressed as the concentration of sucrose.

Inorganic phosphorus: The inorganic Phosphorus (Pi) was measured by the method of Taussky and Shorr [14], using ammonium molybdate. Phosphorus is complexed by an excess of ammonium molybdate and the complex formed is then reduced by ferrous sulphate, giving a blue colour. To a volume of $0.5 \mathrm{ml}$ serum were added $1 \mathrm{ml}$ of $2.5 \% \mathrm{TCA}$ and $3 \mathrm{ml}$ of the reagent. After cooling, absorbance was read at a wavelength of $410 \mathrm{~nm}$ and compared with the control $(0.5 \mathrm{ml}$ of distilled water +1 $\mathrm{ml} 2.5 \% \mathrm{TCA}+3 \mathrm{ml}$ of reagent).

Thiol compounds: The thiol compounds (R-SH) were measured according to the method of Boyne and Ellman [15], using acid dinitro-2,2'-dithio-5-5'-dibenzoic or DTNB. The compounds R-SH reacts with DTNB to give TNB which strongly absorbs at the wavelength of $410 \mathrm{~nm}$ (reaction of Ellman) and the TNB is formed in the buffer (yellow colour). To a volume of $1.5 \mathrm{ml}$ serum were added $50 \mu \mathrm{l}$ of DTNB and $1 \mathrm{ml}$ of Tris of $0.5 \mathrm{M}$. After shaking, absorbance was read at a wavelength of $410 \mathrm{~nm}$ and compared with the control $(1.5 \mathrm{ml} 2.5 \% \mathrm{TCA}+50 \mu \mathrm{l}$ of DTNB $+1 \mathrm{ml}$ of $0.5 \mathrm{M}$ Tris).

\subsection{Visual Estimation of the Panel Dryness}

The quick measurement method of tapping panel dryness was done by visual assessment. The trees were scored on a $0-6$ scale based on the progress of panel dryness as follows:

0: Safe panel, normal flow of latex all over the whole length;

1: Tapping panel dryness over 1 to $20 \%$ of the length $\left(\mathrm{n}_{1}\right)$;

2: Tapping panel dryness over 21 to $40 \%$ of the length (less than a half) $\left(\mathrm{n}_{2}\right)$;

3: Tapping panel dryness over 41 to $60 \%$ of the length (half of the length) $\left(\mathrm{n}_{3}\right)$;

4: Tapping panel dryness over 61 to $80 \%$ of the length (more than a half) $\left(\mathrm{n}_{4}\right)$;
5: Tapping panel dryness over 81 to $100 \%$ of the length (nearly all the panel is dry) $\left(\mathrm{n}_{5}\right)$;

6: Tree tapped but not producing latex, tapping will be $\operatorname{stopped}\left(\mathrm{n}_{6}\right)$.

For each plot, the exact count of the condition of trees was made. The percentage of total dry cut (\% D.C.) for each treatment was calculated as follows:

$$
\text { D.C. }(\%)=\left(0.1 n_{1}+0.3 n_{2}+0.5 n_{3}+0.7 n_{4}+0.9 n_{5}+n_{6}+\text { DT }\right) \times N^{-1}
$$

With: N: Total number of trees; $\mathrm{n}_{\mathrm{i}}$ : Number of trees per class of tapping panel dryness; DT: Number of trees which tapping has been already stopped because of total tapping panel dryness (Dry Trees). The coefficients $0.1,0.3,0.5,0.7$, 0.9 and 1 were defined as the average percentage of tapping panel dryness of the class considered. For each treatment, the percentage of trees completely dry (TPD) was determined by the following relation:

$$
\operatorname{TPD}(\%)=\left(\mathrm{n}_{6}+\mathrm{DT}\right) \times \mathrm{N}^{-1}
$$

\subsection{Statistical Analysis}

The rubber production, plant growth and the latex analysis data were subjected to analysis of variance using statistics software Statistica 7.1. The level of significance of the differences between averages was estimated by the NewmanKeuls test at 5\% probability level.

\section{Results}

\subsection{Dry Rubber Production}

Average dry rubber production expressed in grams per tree per tapping $\left(\mathrm{g} \mathrm{t}^{-1} \mathrm{t}^{-1}\right)$ is reported in Table 1. The productivity of trees, at all sites, is in acceptable level (from 60.37 to $72.81 \mathrm{~g} \mathrm{t}^{-1} \mathrm{t}^{-1}$ ). Early upward tapping, even in very early years of tapping i.e. at 6 years (A: $5 \%$ and B: $2.5 \%$ ) was significantly more productive (71.69 to $72.81 \mathrm{~g} \mathrm{t}^{-1} \mathrm{t}^{-1}$ ) than classic upward tapping (control J, $60.37 \mathrm{~g} / \mathrm{t} / \mathrm{t}$ ) over the 8 years of experimentation. At the same time, rubber production expressed in kilograms per hectare per year $(\mathrm{kg}$ $\mathrm{ha}^{-1} \mathrm{y}^{-1}$ ) and production gain as a function of the control treatment (classic upward tapping: 10 years, J) are presented in Table 2. The results illustrated in this table show that the average values of the rubber production of the treatments of the early upward tapping at 6, 7,8 and 9 years statistically less different to each other and differ from the control treatment $(\mathrm{J})$, classic upward tapping at 10 years. However, combined results of early upward tapping (5\% A and $2.5 \% \mathrm{~B}$ treatments) in all sites, seems to be more interesting with 18 to $20 \%$ gain, with the upward tapping practiced from the $6^{\text {th }}$ year of upward tapping than upward to tapping at $7^{\text {th }}$ year $(13.31$ and $13.62 \%)$. Those trees subjected to upward tapping at 8 and 9 years (E, F, G and $\mathrm{H})$ induce relatively low gain in rubber production ranging from 3.22 to $9.75 \%$. 
Table 1. Average annual production and cumulative production of rubber expressed in gram per tree per tap and tapping at all sites.

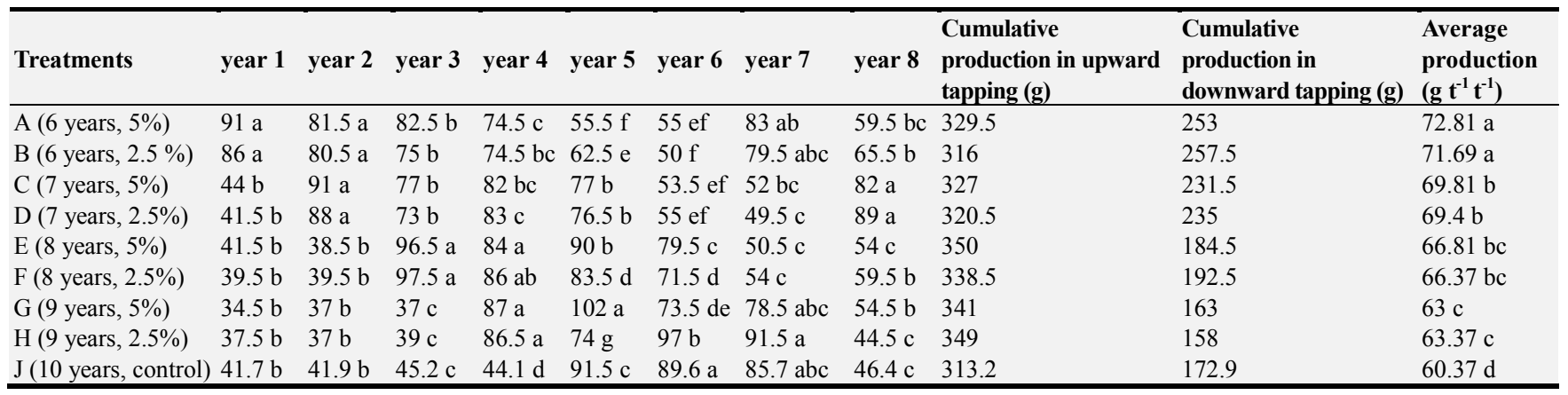

Average values in bold corresponding at the average annual production of rubber during the upward tapping $\mathrm{g}$ : gram, $\mathrm{g} \mathrm{t}^{-1} \mathrm{t}^{-1}$ gram per tree per tapping. year = year of tapping

Table 2. Rubber production expressed in kilograms per hectare per year for all sites combined.

\begin{tabular}{|c|c|c|c|c|c|c|c|c|c|c|}
\hline Treatments & year 1 & year 2 & year 3 & year 4 & year 5 & Year 6 & year 7 & year 8 & $\begin{array}{l}\text { Average value of } \\
\text { production }\left(\mathrm{kg} \mathrm{ha}^{-1} \mathrm{y}^{-1}\right)\end{array}$ & $\begin{array}{l}\text { Gain }(\%) \text { of production } \\
\text { compared to the control } \\
\text { treatment }\end{array}$ \\
\hline A (6 years, $5 \%)$ & $3797 \mathrm{a}$ & $3400 \mathrm{~b}$ & $3431 \mathrm{~b}$ & $3100 \mathrm{~b}$ & $2348 \mathrm{~g}$ & $2309 \mathrm{e}$ & $3458 \mathrm{a}$ & $2488 \mathrm{~d}$ & $3041.38 \mathrm{a}$ & 20.32 \\
\hline B (6 years, $2.5 \%)$ & 3569 a & $3332 \mathrm{~b}$ & $3118 b$ & $3094 \mathrm{~b}$ & $2595 \mathrm{fg}$ & $2073 \mathrm{e}$ & $3309 \mathrm{ab}$ & $2770 \mathrm{c}$ & $2982.50 \mathrm{a}$ & 18.00 \\
\hline $\mathrm{C}(7$ years, $5 \%)$ & $1724 \mathrm{~b}$ & 3788 a & $3196 \mathrm{~b}$ & $3403 \mathrm{ab}$ & 3093 def & $2209 \mathrm{e}$ & $2161 \mathrm{~b}$ & $3403 \mathrm{~b}$ & $2872.12 \mathrm{ab}$ & 13.62 \\
\hline $\mathrm{D}(7$ years, $2.5 \%)$ & $1727 b$ & $3663 \mathrm{ab}$ & $3046 \mathrm{~b}$ & $3449 \mathrm{ab}$ & 3014 ef & 2293 e & $2050 \mathrm{~b}$ & $3673 \mathrm{a}$ & $2864.37 \mathrm{ab}$ & 13.31 \\
\hline E (8 years, $5 \%)$ & $1723 \mathrm{~b}$ & $1585 \mathrm{c}$ & 4029 a & $3468 \mathrm{ab}$ & $3731 \mathrm{abc}$ & $3300 \mathrm{c}$ & $2107 \mathrm{~b}$ & $2252 \mathrm{~d}$ & $2774.37 \mathrm{ab}$ & 9.75 \\
\hline $\mathrm{G}(9$ years, $5 \%)$ & $1435 \mathrm{~b}$ & $1548 \mathrm{c}$ & $1551 \mathrm{c}$ & $3588 \mathrm{a}$ & $4213 \mathrm{a}$ & $3032 \mathrm{~d}$ & $3265 \mathrm{ab}$ & $2241 \mathrm{~d}$ & 2609.12 b & 3.22 \\
\hline H (9 years, $2.5 \%)$ & $1570 \mathrm{~b}$ & $1535 \mathrm{c}$ & $1638 \mathrm{c}$ & 3579 a & 3345 cde & 4094 a & $3792 \mathrm{a}$ & $1843 \mathrm{e}$ & $2674.50 \mathrm{~b}$ & 5.80 \\
\hline $\mathrm{J}$ (10 years, control) & $1734 \mathrm{~b}$ & $1744 \mathrm{c}$ & $1881 \mathrm{c}$ & $1833 \mathrm{c}$ & $3807 \mathrm{ab}$ & $3726 \mathrm{~b}$ & $3565 \mathrm{a}$ & $1932 \mathrm{e}$ & $2527.75 \mathrm{c}$ & 0.00 \\
\hline
\end{tabular}

Average values in bold corresponding to the average annual production of rubber during the upward tapping.

$\mathrm{Kg}^{-1} \mathrm{ha}^{-1} \mathrm{y}^{-1}$ : kilogram per hectare per year

\subsection{Average Annual Increase in Tree Girth}

Annual mean growth rates of tree circumference expressed in centimeters per year $(\mathrm{cm} / \mathrm{y})$ for all sites are reported in Table 3 . The trees of all treatments showed high mean annual increase in girth. These rates range from 2.40 (control treatment $\mathrm{J}$, at 10 years) to $3.03 \mathrm{~cm} / \mathrm{y}$ (A: upward tapping at 6 years, 5\%). In addition, trees tapped in early upward tapping 6,7 and even at 8 years $(\mathrm{A}, \mathrm{B}, \mathrm{C}, \mathrm{D}, \mathrm{E}$ and $\mathrm{F})$ showed higher mean annual increments $(2.91 \mathrm{~cm} / \mathrm{y})$. These increases were statistically greater in Treatments A and B than in Control J. The mean annual circumference increment of the very early upward tapping at $6^{\text {th }}$ year $\left(\mathrm{A}, 3.025 \mathrm{~cm} \mathrm{y}^{-1}\right)$, at all sites and both levels of ethephon stimulation, was statistically greater than that of the control (J, $2.40 \mathrm{~cm} / \mathrm{y})$. This equates to a vegetative growth gain in trees tapped upward at $6^{\text {th }}$ year compared to the control (J) by $26 \%$.

\subsection{Tapping Panel Dryness}

The rate of tapping panel dryness is shown in Table 4. The highest rate of dry tapping cut length (DC), 21.10\% was recorded in control treatment $\mathrm{J}$ (classic upward tapping at 10 years). It is statistically higher than those of early upward tapping, especially the tapping at $6^{\text {th }}$ year (A, 7.95\% and B, $8.25 \%)$. Regarding the average rate of totally dry trees, the early upward tapping, especially in $6^{\text {th }}$ year $(\mathrm{A}, 5.75 \%$ and $\mathrm{B}$, $6.30 \%)$, were in the same order of magnitude as the control treatment $\mathrm{J}$ (7.85), regardless of the sites of study.
Table 3. Average circumference at the beginning and end of the experiment and annual circumference increases during the 8 years of the study.

\begin{tabular}{|c|c|c|c|c|c|c|}
\hline \multirow{2}{*}{$\frac{\text { Treatments }}{\text { A }(6 \text { years, } 5 \%)}$} & \multicolumn{2}{|c|}{ Gir-i (mm) } & \multicolumn{2}{|c|}{ Gir-f (mm) } & \multicolumn{2}{|c|}{ Gin m.a (cm year $\left.{ }^{-1}\right)$} \\
\hline & $674.5 \mathrm{a}$ & $\mathrm{a}$ & 917 & $\mathrm{a}$ & 3.03 & a \\
\hline B (6 years, $2.5 \%)$ & $675 \mathrm{a}$ & $\mathrm{a}$ & 916.5 & $\mathrm{a}$ & 3.02 & $\mathrm{a}$ \\
\hline C (7 years, $5 \%)$ & $678.5 \mathrm{a}$ & $\mathrm{a}$ & 904.5 & $\mathrm{a}$ & 2.83 & $a b$ \\
\hline D (7 years, $2.5 \%)$ & $674 \mathrm{a}$ & $\mathrm{a}$ & 895 & $\mathrm{a}$ & 2.76 & $a b$ \\
\hline E $(8$ years, $5 \%)$ & $657 \mathrm{a}$ & $\mathrm{a}$ & 883.5 & $\mathrm{a}$ & 2.83 & $a b$ \\
\hline $\mathrm{F}(8$ years, $2.5 \%)$ & $674 \mathrm{a}$ & $\mathrm{a}$ & 914 & $\mathrm{a}$ & 3.00 & $\mathrm{a}$ \\
\hline G $(9$ years, $5 \%)$ & $681 \mathrm{a}$ & $\mathrm{a}$ & 878 & $\mathrm{a}$ & 2.47 & $\mathrm{~b}$ \\
\hline H (9 years, $2.5 \%)$ & $681.5 \mathrm{a}$ & $\mathrm{a}$ & 881.5 & $\mathrm{a}$ & 2.50 & $b$ \\
\hline $\mathrm{J}$ (10 years, control) & $678 \mathrm{a}$ & $\mathrm{a}$ & 870 & $\mathrm{a}$ & 2.40 & $\mathrm{~b}$ \\
\hline Mean & 674.8 & & 895.5 & & 2.76 & \\
\hline \multicolumn{7}{|c|}{$\begin{array}{l}\text { Gir } \mathrm{i} / \mathrm{f}(\mathrm{mm}) \text { : Mean value of circumference at the beginning (i) and end of } \\
\left.\text { the experiment (f) Gin m.a.: Annual circumference increases (cm.year }{ }^{-1}\right) \\
\text { during the } 8 \text { years of the study }\end{array}$} \\
\hline
\end{tabular}

Table 4. Average of dry tapping cut length rates and tapping panel dryness of trees over 8 years of experimentation.

\begin{tabular}{|c|c|c|c|c|}
\hline Treatments & DC & & TPD & \\
\hline A (6 years, $5 \%)$ & 7.95 & $\mathrm{~b}$ & 5.75 & a \\
\hline B (6 years, $2.5 \%)$ & 8.25 & $\mathrm{~b}$ & 6.30 & a \\
\hline $\mathrm{C}(7$ years, $5 \%)$ & 6.55 & $\mathrm{~b}$ & 4.25 & a \\
\hline D (7 years, $2.5 \%)$ & 6.40 & $\mathrm{~b}$ & 4.25 & a \\
\hline E (8 years, $5 \%)$ & 6.60 & $\mathrm{~b}$ & 3.95 & a \\
\hline F (8 years, $2.5 \%)$ & 3.80 & $\mathrm{~b}$ & 2.20 & a \\
\hline G (9 years, $5 \%)$ & 9.80 & $\mathrm{~b}$ & 1.90 & a \\
\hline H (9 years, $2.5 \%)$ & 10.20 & $\mathrm{~b}$ & 2.55 & a \\
\hline $\mathrm{J}$ (10 years, control) & 21.10 & $\mathrm{a}$ & 7.85 & a \\
\hline Mean & 8.96 & & 4.33 & \\
\hline
\end{tabular}




\subsection{Physiological Profile of Trees Under Early Upward Tapping}

The results of the studies on physiological parameters viz., dry rubber content (DRC), sucrose (Suc), inorganic phosphorus (Pi) and thiol groups of the latex (R-SH) are reported in the tables 5, 6, 7 and 8). The mean dry rubber content (DRC) was not significantly different among different treatments, but were relatively high $(>43 \%)$ regardless of the tapping system, in the experiment (Table 5). The mean values, during 8 years of testing, range from 47 to $52.50 \%$ for the Treatment J (classic upward tapping at 10 years), Treatment D (early upward tapping at 7 year) and Treatment E (early upward tapping at 8years) respectively. The average sucrose (Suc.) contents in the latex was on par at the beginning of the test and values attributed as medium to very high (11.05 to $19.46 \mathrm{mmol} \mathrm{l}^{-1}$, Table 6). However, with the exception of upward tapping at 8,9 and 10 years, a general downward trend in this content was observed for treatments A, B, C and D during the experiment. The control treatment $\mathrm{J}$ (classic upward tapping at 10 years) recorded a mean value of the sucrose content of $12.40 \mathrm{mmol} \mathrm{l}^{-1}$ vs 13.82 and $15.35 \mathrm{mmol} \mathrm{l}^{-1}$ respectively for the very early treatments of upward tapping at 6 years $(A$ and $B)$ and early, tapping at 7,8 and 9 years $(C, D$, $\mathrm{E}, \mathrm{F}, \mathrm{G}$ and $\mathrm{H})$. The inorganic phosphorus content (Pi) was negatively influenced by the delay in upward tapping. In both sites, it showed a drastic drop in the $3^{\text {rd }}$ year of experimentation regardless of the treatment applied (Table 7). During the study period, the average values ranged from 18.12 to $7.22 \mathrm{mmol} \mathrm{l}^{-1}$; from 21.75 to $6.57 \mathrm{mmol} \mathrm{l}^{-1}$ and from 21.80 to $5.00 \mathrm{mmol}^{-1}$. This variation is due to the difference between treatments: treatments very early (A and B, upward tapping at 6 years); early treatments $(\mathrm{C}$ and $\mathrm{D}$, upward tapping at 7, E and F, upward tapping at 8 and $\mathrm{G}$ and $\mathrm{H}$, upward tapping at 9). The overall levels of thiols (Table 8) ranged from 0.33 to $0.45 \mathrm{mmol}^{-1}$ at the beginning of the experiment, achieved a good recovery, ranging from 0.55 to $1.15 \mathrm{mmol}^{-1}$ at the end of the study, regardless of the delay of early upward tapping applied.

Table 5. Dry Rubber Content rates under different early upward tapping treatments, all sites combined.

\begin{tabular}{|c|c|c|c|c|c|c|c|c|c|c|c|c|c|c|c|c|c|c|}
\hline Treatements & year 1 & & year 2 & & year 3 & & year 4 & & year 5 & & year 6 & & year 7 & & year 8 & & Mean & years) \\
\hline A (6 years, $5 \%)$ & 53.20 & $\mathrm{a}$ & 45.20 & $\mathrm{a}$ & 53.95 & a & 54.45 & a & 60.60 & $\mathrm{a}$ & 45.45 & $\mathrm{a}$ & 49.75 & $\mathrm{a}$ & 50.05 & $\mathrm{a}$ & 51.50 & $\mathrm{a}$ \\
\hline $\mathrm{B}(6$ years, $2.5 \%)$ & 53.45 & $\mathrm{a}$ & 47.60 & $\mathrm{a}$ & 53.50 & a & 54.50 & a & 55.60 & $\mathrm{a}$ & 44.55 & a & 49.55 & $\mathrm{a}$ & 51.85 & $\mathrm{a}$ & 51.00 & $\mathrm{a}$ \\
\hline C (7 years, $5 \%)$ & 49.05 & $\mathrm{a}$ & 46.30 & a & 51.75 & a & 54.20 & a & 56.40 & $\mathrm{a}$ & 44.05 & $\mathrm{a}$ & 46.60 & $\mathrm{a}$ & 50.95 & $\mathrm{a}$ & 49.50 & $\mathrm{a}$ \\
\hline D (7 years, $2.5 \%)$ & 51.85 & $\mathrm{a}$ & 48.40 & a & 53.05 & a & 53.70 & $\mathrm{a}$ & 56.15 & $\mathrm{a}$ & 51.20 & a & 53.10 & $\mathrm{a}$ & 53.30 & $\mathrm{a}$ & 52.50 & a \\
\hline E $(8$ years, $5 \%)$ & 52.70 & $\mathrm{a}$ & 45.60 & $\mathrm{a}$ & 54.60 & $\mathrm{a}$ & 53.45 & $\mathrm{a}$ & 53.95 & a & 57.55 & a & 51.00 & a & 52.00 & a & 52.50 & a \\
\hline F (8 years, $2.5 \%)$ & 48.40 & $\mathrm{a}$ & 44.95 & a & 51.05 & a & 54.85 & $\mathrm{a}$ & 50.70 & $\mathrm{a}$ & 47.85 & a & 50.05 & a & 51.15 & $\mathrm{a}$ & 49.50 & a \\
\hline $\mathrm{G}(9$ years, $5 \%)$ & 47.95 & $\mathrm{a}$ & 43.75 & $\mathrm{a}$ & 45.95 & $\mathrm{a}$ & 52.75 & $\mathrm{a}$ & 54.40 & $\mathrm{a}$ & 42.90 & a & 49.30 & $\mathrm{a}$ & 48.00 & $\mathrm{a}$ & 47.50 & $\mathrm{a}$ \\
\hline $\mathrm{H}(9$ years, $2.5 \%)$ & 48.30 & $\mathrm{a}$ & 46.40 & $\mathrm{a}$ & 49.40 & $\mathrm{a}$ & 53.15 & $\mathrm{a}$ & 52.25 & $\mathrm{a}$ & 43.10 & a & 45.15 & a & 46.75 & $\mathrm{a}$ & 48.00 & a \\
\hline J (10 years, control) & 51.50 & $\mathrm{a}$ & 45.05 & a & 48.90 & a & 40.25 & a & 54.80 & a & 45.25 & a & 51.40 & a & 46.90 & a & 47.00 & a \\
\hline Mean & 50.71 & & 45.91 & & 51.35 & & 52.36 & & 54.98 & & 46.87 & & 49.54 & & 50.10 & & 49.88 & \\
\hline
\end{tabular}

Table 6. Sucrose content in mmol $l^{-1}$ under different early upward tapping treatments (all sites combined).

\begin{tabular}{|c|c|c|c|c|c|c|c|c|c|c|c|c|c|c|c|c|c|c|}
\hline Treatments & year 1 & & year 2 & & year 3 & & year 4 & & year 5 & & year 6 & & year 7 & & year 8 & & Mean & ears) \\
\hline A (6 years, $5 \%)$ & 17.60 & $\mathrm{a}$ & 15.65 & $\mathrm{ab}$ & 17.10 & $\mathrm{a}$ & 16.40 & $\mathrm{bc}$ & 13.20 & $\mathrm{bc}$ & 6.25 & $\mathrm{~b}$ & 9.10 & $\mathrm{c}$ & 13.30 & $\mathrm{bc}$ & 13.75 & $\mathrm{a}$ \\
\hline B (6 years, $2.5 \%)$ & 19.46 & $\mathrm{a}$ & 17.20 & $a b$ & 16.05 & $\mathrm{bc}$ & 14.35 & $a b c$ & 12.00 & $\mathrm{bc}$ & 8.50 & $\mathrm{~b}$ & 11.65 & $\mathrm{bc}$ & 13.40 & bc & 13.90 & $\mathrm{a}$ \\
\hline C (7 years, $5 \%)$ & 10.80 & $\mathrm{a}$ & 15.25 & $a b$ & 18.45 & $\mathrm{a}$ & 17.30 & $\mathrm{a}$ & 15.65 & $\mathrm{a}$ & 8.60 & $\mathrm{~b}$ & 12.45 & $a b c$ & 14.15 & $a b c$ & 14.65 & $\mathrm{a}$ \\
\hline $\mathrm{D}(7$ years, $2.5 \%)$ & 17.25 & a & 20.50 & $\mathrm{a}$ & 13.56 & $a b c$ & 20.25 & $\mathrm{a}$ & 14.95 & $a b$ & 13.00 & $a b$ & 14.65 & $a b c$ & 14.35 & $a b c$ & 16.90 & $\mathrm{a}$ \\
\hline E (8 years, $5 \%)$ & 13.30 & $\mathrm{a}$ & 11.55 & $\mathrm{ab}$ & 13.60 & $a b c$ & 15.45 & $a b c$ & 16.90 & $\mathrm{a}$ & 21.15 & $a b$ & 13.00 & $a b c$ & 15.70 & $a b c$ & 15.45 & $\mathrm{a}$ \\
\hline $\mathrm{F}(8$ years, $2.5 \%)$ & 11.05 & a & 14.10 & $a b$ & 13.75 & $a b c$ & 15.55 & $a b c$ & 13.50 & $a b$ & 15.85 & $a b$ & 18.70 & $a b$ & 15.70 & $a b c$ & 14.95 & $\mathrm{a}$ \\
\hline G $(9$ years, $5 \%)$ & 11.50 & a & 9.30 & $\mathrm{~b}$ & 7.00 & c & 17.05 & $\mathrm{a}$ & 16.55 & $\mathrm{a}$ & 26.45 & $\mathrm{a}$ & 20.90 & $\mathrm{a}$ & 16.10 & $a b c$ & 15.60 & a \\
\hline H (9 years, $2.5 \%)$ & 11.75 & a & 8.70 & $\mathrm{~b}$ & 6.10 & $\mathrm{c}$ & 14.95 & $a b c$ & 15.05 & a & 27.55 & $\mathrm{a}$ & 17.20 & $a b c$ & 18.60 & $\mathrm{ab}$ & 14.60 & a \\
\hline $\mathrm{J}$ (10 years, control) & 12.60 & $\mathrm{a}$ & 8.40 & $\mathrm{~b}$ & 7.15 & $\mathrm{bc}$ & 7.65 & $\mathrm{c}$ & 15.26 & $\mathrm{a}$ & 21.45 & $a b$ & 13.75 & $a b c$ & 20.40 & $\mathrm{a}$ & 12.40 & $\mathrm{a}$ \\
\hline Mean & 13.92 & & 13.41 & & 12.53 & & 15.44 & & 14.52 & & 16.53 & & 14.60 & & 15.74 & & 14.69 & \\
\hline
\end{tabular}

Table 7. Inorganic phosphorus content in mmol $l^{-1}$ under different early upward tapping treatments (all sites combined).

\begin{tabular}{|c|c|c|c|c|c|c|c|c|c|c|c|c|c|c|c|c|c|c|}
\hline Traitements & year 1 & & year 2 & & year 3 & & year 4 & & year 5 & & year 6 & & year 7 & & year 8 & & Mean & ears) \\
\hline A (6 years, $5 \%)$ & 17.35 & $\mathrm{~b}$ & 15.20 & $\mathrm{a}$ & 3.85 & a & 10.95 & $\mathrm{~b}$ & 11.90 & $\mathrm{~b}$ & 11.70 & $\mathrm{a}$ & 8.75 & $\mathrm{a}$ & 8.20 & a & 10.95 & $\mathrm{a}$ \\
\hline B (6 years, $2.5 \%)$ & 18.90 & $a b$ & 15.95 & $\mathrm{a}$ & 4.70 & a & 10.70 & $\mathrm{~b}$ & 11.10 & $b$ & 10.90 & $a b$ & 7.70 & $b$ & 6.25 & b & 10.65 & $\mathrm{a}$ \\
\hline C (7 years, $5 \%)$ & 21.15 & $a b$ & 15.25 & $\mathrm{a}$ & 4.70 & $\mathrm{a}$ & 10.30 & $\mathrm{~b}$ & 12.20 & $a b$ & 11.50 & $\mathrm{a}$ & 5.60 & $\mathrm{~b}$ & 7.85 & $\mathrm{~b}$ & 10.95 & $\mathrm{a}$ \\
\hline D (7 years, $2.5 \%)$ & 23.35 & $\mathrm{a}$ & 13.40 & $\mathrm{a}$ & 5.60 & $\mathrm{a}$ & 10.15 & $\mathrm{~b}$ & 12.05 & $a b$ & 7.95 & $\mathrm{~b}$ & 7.10 & $\mathrm{~b}$ & 5.15 & $\mathrm{~b}$ & 10.20 & $\mathrm{a}$ \\
\hline E $(8$ years, $5 \%)$ & 22.15 & $a b$ & 17.35 & $\mathrm{a}$ & 6.65 & a & 11.35 & $\mathrm{~b}$ & 8.30 & $\mathrm{~b}$ & 6.50 & $\mathrm{~b}$ & 4.85 & $\mathrm{~b}$ & 5.55 & b & 10.15 & $\mathrm{a}$ \\
\hline F (8 years, $2.5 \%)$ & 21.00 & $a b$ & 15.45 & $\mathrm{a}$ & 4.95 & a & 10.05 & b & 15.55 & a & 10.80 & $a b$ & 6.55 & $b$ & 8.45 & a & 11.50 & a \\
\hline G (9 years, $5 \%)$ & 20.55 & $a b$ & 17.85 & $\mathrm{a}$ & 8.05 & $\mathrm{a}$ & 12.00 & b & 12.05 & $a b$ & 5.95 & $\mathrm{~b}$ & 8.05 & a & 5.60 & b & 11.10 & $\mathrm{a}$ \\
\hline $\mathrm{H}(9$ years, $2.5 \%)$ & 22.30 & $a b$ & 17.20 & $\mathrm{a}$ & 6.00 & $\mathrm{a}$ & 12.25 & $\mathrm{~b}$ & 7.65 & $\mathrm{~b}$ & 7.05 & $\mathrm{~b}$ & 5.60 & $\mathrm{~b}$ & 6.80 & $\mathrm{~b}$ & 10.40 & a \\
\hline $\mathrm{J}$ (10 years, control) & 21.80 & $a b$ & 16.85 & $\mathrm{a}$ & 5.35 & a & 16.40 & $\mathrm{a}$ & 8.20 & $b$ & 8.85 & $\mathrm{~b}$ & 6.80 & $b$ & 5.00 & $\mathrm{~b}$ & 10.85 & $\mathrm{a}$ \\
\hline Mean & 20.94 & & 16.06 & & 5.48 & & 11.52 & & 11.00 & & 9.02 & & 6.78 & & 6.54 & & 10.75 & \\
\hline
\end{tabular}


Table 8. Thiol content in mmol $l^{-1}$ under different early upward tapping treatments (all sites combined).

\begin{tabular}{|c|c|c|c|c|c|c|c|c|c|c|c|c|c|c|c|c|c|c|}
\hline \multirow{2}{*}{$\frac{\text { Treatments }}{\text { A (6 years, } 5 \%)}$} & \multicolumn{2}{|c|}{ year 1} & \multicolumn{2}{|c|}{ year 2} & \multicolumn{2}{|c|}{ year 3} & \multicolumn{2}{|c|}{ year 4} & \multicolumn{2}{|c|}{ year 5} & \multicolumn{2}{|c|}{ year 6} & \multicolumn{2}{|c|}{ year 7} & \multicolumn{2}{|c|}{ year 8} & \multicolumn{2}{|c|}{ (mean years) } \\
\hline & 0.43 & a & 0.61 & a & 0.28 & $\mathrm{a}$ & 0.91 & $\mathrm{a}$ & 1.12 & $\mathrm{~b}$ & 0.30 & a & 0.75 & $\mathrm{~b}$ & 0.56 & $\mathrm{~b}$ & 0.62 & $\mathrm{a}$ \\
\hline B (6 years, $2.5 \%)$ & 0.40 & $\mathrm{a}$ & 0.56 & $\mathrm{a}$ & 0.26 & $\mathrm{a}$ & 0.86 & $\mathrm{a}$ & 1.3 & $\mathrm{~b}$ & 0.26 & $\mathrm{a}$ & 0.59 & $\mathrm{~b}$ & 0.66 & $\mathrm{~b}$ & 0.59 & $\mathrm{a}$ \\
\hline C (7 years, $5 \%)$ & 0.40 & $\mathrm{a}$ & 0.58 & a & 0.28 & $\mathrm{a}$ & 0.96 & a & 1.85 & b & 0.25 & a & 0.66 & $\mathrm{~b}$ & 0.65 & $\mathrm{~b}$ & 0.70 & $\mathrm{a}$ \\
\hline D (7 years, $2.5 \%$ ) & 0.45 & $\mathrm{a}$ & 0.60 & $\mathrm{a}$ & 0.29 & $\mathrm{a}$ & 0.97 & a & 1.11 & $\mathrm{~b}$ & 0.23 & a & 0.86 & $\mathrm{ab}$ & 0.74 & $\mathrm{ab}$ & 0.66 & $\mathrm{a}$ \\
\hline E (8 years, $5 \%)$ & 0.44 & $\mathrm{a}$ & 0.49 & $\mathrm{a}$ & 0.31 & $\mathrm{a}$ & 0.94 & a & 2.12 & $\mathrm{ab}$ & 0.26 & $\mathrm{a}$ & 0.96 & $\mathrm{a}$ & 1.15 & $\mathrm{a}$ & 0.83 & $\mathrm{a}$ \\
\hline $\mathrm{F}(8$ years, $2.5 \%)$ & 0.43 & a & 0.59 & a & 0.28 & $\mathrm{a}$ & 0.94 & a & 1.41 & $\mathrm{~b}$ & 0.30 & a & 0.83 & $a b$ & 0.68 & $\mathrm{~b}$ & 0.68 & $\mathrm{a}$ \\
\hline G (9 years, $5 \%)$ & 0.33 & $\mathrm{a}$ & 0.56 & $\mathrm{a}$ & 0.29 & $\mathrm{a}$ & 1.08 & $\mathrm{a}$ & 1.41 & $\mathrm{~b}$ & 0.24 & $\mathrm{a}$ & 0.94 & $\mathrm{a}$ & 0.55 & $\mathrm{~b}$ & 0.67 & $\mathrm{a}$ \\
\hline $\mathrm{H}(9$ years, $2.5 \%)$ & 0.39 & $\mathrm{a}$ & 0.53 & $\mathrm{a}$ & 0.21 & $\mathrm{a}$ & 1.05 & $\mathrm{a}$ & 2.11 & $a b$ & 0.31 & $\mathrm{a}$ & 0.93 & $\mathrm{a}$ & 0.70 & $a b$ & 0.77 & $\mathrm{a}$ \\
\hline $\mathrm{J}$ (10 years, control) & 0.43 & $\mathrm{a}$ & 0.53 & a & 0.23 & $\mathrm{a}$ & 0.96 & a & 2.41 & $\mathrm{a}$ & 0.23 & a & 1.00 & $\mathrm{a}$ & 0.67 & $\mathrm{~b}$ & 0.80 & $\mathrm{a}$ \\
\hline Mean & 0.41 & & 0.56 & & 0.27 & & 0.96 & & 1.65 & & 0.26 & & 0.84 & & 0.71 & & 0.70 & \\
\hline
\end{tabular}

\section{Discussion}

\subsection{Dry Rubber Production}

The dry rubber production data expressed in $\mathrm{kgha}^{-1} \mathrm{y}^{-1}$ of early upward tapping are convincing, given the production gains that they made possible in the first four years of tapping (production gain $\geq 30 \%$ per year) compared to $\mathrm{J},[3$, 16]. Production of rubber is strongly and positively influenced by the number of stimulation applications for a given clone and the latex harvesting technology [17-21] and also by the concentration of ethephon [21]. The practice of hormonal stimulation allows a substantial increase in production by increasing the flow time [22]. It also induces rubber production in upward tapping $[2,23]$, and depends on the strength of stimulant $(2.5 \%$ ET in downward vs 5\% ET in upward) which may ultimately effected by the activation of the latex generation metabolism and availability of raw material (sucrose) [24]. This assertion is supported by the work of Obouayeba et al., [4, 23]. The improvement of the production by the upward tapping was demonstrated by earlier studies [23] and [25]. There is a four years' time saving in very early upward tapping at 6 years when compared to the control treatment trees (classic upward tapping at 10 years). Moreover, these results make it possible to address the problem of delayed yield in plantations. This strategy leads to a gain in time of harvesting in high panel (HO) and certainly a good increase in the total production. Indeed, it is more plausible, to make four years of upward tapping on virgin bark, unlike the current practice, which does not exceed three years of upward tapping. The time of the latex harvesting could thus reach 40 years. Moreover, these results provide a solution to the issue of very high bark consumption rate in lower panel.

\subsection{Radial Vegetative Growth}

The mean annual increase in circumference of trees under upward tapping at 6 years was $3.025 \mathrm{~cm} \mathrm{y}^{-1}$ which was significantly greater than that of the control $\left(2.40 \mathrm{~cm} \mathrm{y}^{-1}\right)$. Despite early upward tapping, analysis of average increase in tree circumference showed that they had high average annual growth rates. The trees tapped in the classic upward tapping at 10 years show the lowest average annual circumference growth rates. This revealed that starting upward tapping at early stages had a positive effect on tree growth. This is a good indication that early ie., 6, 7, 8 and 9 years (A to $\mathrm{H}$ ) upward tapping was not detrimental to the vegetative radial growth of the clone GT 1. Work of Nair [3] and Obouayeba et al [4] had also proven that the upward tapping from the $6^{\text {th }}$ year (A and B) was the best time of upward tapping of clone GT 1 and probably other clones with moderate metabolism.

\subsection{Sensitivity to Tapping Panel Dryness}

Regardless of the sites of study, rate of dry tapping cut length (DC\%) were in the same order of magnitude, except for trees tapped with classic upward tapping at 10 years, which showed that the highest DC levels, at 21\% (Table 4). TPD rates were acceptable as the average dry tree rate was less than $10 \%$ over an eight-year period and lower than that observed (average DC rate $13.2 \%$ and average TPD rate $12.6 \%$, over four to five years) in earlier study [2] in smallholdings, but with trees tapped by upward tapping at 10 years.

\subsection{Physiological Profile of trees}

The physiological profile expresses the health of the rubber trees at a given moment. The physiological profile was evaluated by the analysis of biochemical parameters such as dry rubber content extract (Ex.S), sucrose (Suc), inorganic phosphorus $(\mathrm{Pi})$ and thiol groups (R-SH). The average dry rubber content of the latex was high (control treatment, classic upward tapping at 10 years) to very high (early upward tapping at $6,7,8$ and 9 years) in general. It is of the same order of magnitude for all treatments in early upward tapping regardless of the site (Bettié and Gagnoa). These rates have showed relative increase with time in both sites. Indeed, with an average dry rubber content greater than $50 \%$, this indicated that the biosynthesis of rubber was promising [22]. The sucrose content of the latex was high and in the same order of magnitude for the early upward tapping on all the treatments and the sites. The average sucrose content, was above $10 \mathrm{mmol}$ $\mathrm{I}^{-1}$ overall, and this was a good indication of the availability of sucrose, for isoprene synthesis [26]. It also means that the raw material required for isoprene biosynthesis was not limiting. These results revealed that early upward tapping is not detrimental to rubber production, especially, production in subsequent years. The result of the present study is in confirmation with the conclusions of the work of Obouayeba et al., [4]. The inorganic phosphorus content (Pi) of the latex, 
at the end of the experiment, was lower than that in the beginning regardless of the locality. This decrease was independent of the applied delays in upward tapping and experimental sites. At the beginning, Pi content of latex, of the control treatment, classic upward tapping at 10 years (J), assured the availability of necessary energy for synthesis of rubber. At the end of the experiment, decrease in Pi content reflected a negative influence on the energy availability in laticiferous system. The average content of thiol group (R-SH) of latex was low to medium $\left(0.41\right.$ to $\left.0.71 \mathrm{mmol}^{-1}\right)$ at all sites. It was in the same order of magnitude for all the treatments of the two sites. The average R-SH content was generally high at the end of the experiment compared to that at the beginning. On the other hand, the average R-SH content of the control, classic upward tapping at 10 years $(\mathrm{J})$, was comparable or higher when compared to that of the early upward tapping at 6 , 7, 8 and 9 years (A to $\mathrm{H}$ ) over the 8 years of experimentation. The level of the contents of the different latex harvest systems reflected the fact that the early upward tapping (all tapping delays combined) had no negative impact on the protective mechanisms of the laticiferous system. It further indicated increased stability of latex lutoids. This corroborates the conclusions drawn from the work of Obouayeba et al., [4]. This stability explains high rubber production with early upward tapping and also assures the maintenance of physiological status [4]. The protective systems of latexproducing laticiferous cells were not a limiting factor in the production of rubber. In this case very early (6 years) and even early (7, 8 and 9 years) upward tapping did not negatively influence the physiological state of the rubber trees. Yield gain ranged from 5 to $20 \%$ when compared to the control treatment, classic upward tapping at 10 years $(\mathrm{J})$.

\section{Conclusion}

Irrespective of the site of study, early upward tapping at 6, 7, 8 and 9 years did not negatively affect the radial vegetative growth of trees. Early upward tapping resulted in significant gain in rubber production of up to $12 \%$. This gain reached $20 \%$ with very early upward tapping at 6 years (all sites and concentration in ethephon combined), compared to the control (classic upward tapping at 10 years) during the eight years of experimentation. In addition, the physiological profiles of the trees tapped with early upward tapping were statistically identical to those of the trees tapped with classic upward tapping at 10 years. Early upward tapping did not induce an increase in the TPD rate. According to our investigations, it appears that the early upward tapping at $6,7,8$ and 9 years can be considered to improve the productivity of the rubber tree. Thus, very early upward tapping at 6 years, after 5 years of downward tapping, was certainly the best time to start harvesting latex from the high tapping panel (HO-1).

\section{Conflict of Interest}

On behalf of all authors, the corresponding author states that there is no conflict of interest.

\section{References}

[1] Zhang, C., Yong, L., Chen, Y., Zhang, S., Ge, L., Wang, S., \& LI, W. (2019). A rubber-tapping robot forest navigation and information collection system based on 2D LiDAR and a gyroscope. Sensors, 19(9), 2136.

[2] Gohet, E., Lacote, R., Leconte, A., Chapuset, T., Rivano, F., \& Chambon, B. (2016). Improving rubber smallholdings productivity and resilience through adoption of good agricultural practices. In Paper presented on Conference: Focus Forum on Natural Rubber Sustainability. International Rubber Study Group, Singapore.

[3] Nair, K. P. (2021). Rubber (Hevea brasiliensis). In Tree Crops. Springer, Cham. pp. 287-332.

[4] Obouayeba, S.; Diarrassouba M., Soumahin E. F.; Essehi J. L.; Okoma K. M.; Adou B. Y. C. and Obouayeba A. P. (2016). Latex Harvesting Technologies Adapted to Clones IRCA 18, IRCA 111, IRCA 130, PB 235 and PB 260 of Hevea brasiliensis (Rubber Tree) of the Class to Active Metabolism in South-Western Côte d'Ivoire. J. A. E. R. I., 9(4), 1-14.

[5] Michels T., Eschbach J. M., Lacote R., Benneveau A., \& Papy, F. (2012). Tapping panel diagnosis, an innovative on-farm decision support system for rubber tree tapping. Agronomy for sustainable development, 32(3), 791-801.

[6] Atsin G. J. O., Soumahin E. F., Kouakou T. H., Elabo A. E. A., Okoma K. M., \& Obouayeba S. (2016). Agronomic Potential of Some Rubber Tree Clones (Hevea brasiliensis) of the Fast Metabolic Activity Class in the Absence of Hormonal Stimulation in Southwestern of Côte d'Ivoire. Journal of Experimental Agriculture International, 1-13.

[7] Purwaningrum Y., Asbur Y., \& Junaidi J. (2019). Latex quality and yield parameters of Hevea brasiliensis (Willd. ex A. Juss.) Müll. Arg. clone PB 260 for different tapping and stimulant application frequencies. Chilean journal of agricultural research, 79(3), 347-355.

[8] Anonymous 1. (1993) Hevea clone card collection. CIRADPerennial crops. Montpellier: CIRAD, $20 \mathrm{p}$.

[9] Obouayeba S.; Soumahin E. F. and Coulibaly L. F. (2010) Low intensity tapping systems applied to clone PR 107 of Hevea brasiliensis (Muell. Arg.) in South-eastern Côte d'Ivoire: influence of the nature of the exploited bark and the position of tapping panel. Agriculture and Biology Journal of North America, 1(5), 1106-1118.

[10] Anonymous 2. (2007) Climat: Abengourou. www.fr.climatedata.org.

[11] Anonymous 3. (2007) Climat: Gagnoa. www.fr.climatedata.org.

[12] Brou Y. T. (2005). Climate, socio-economic changes and landscapes in Côte d'Ivoire. Dissertation of synthesis of the scientific activities presented in view of obtaining the Habilitation to Direct Research. Universities of Science and Technology of Lille, $213 \mathrm{p}$.

[13] Obouayeba S. (1993) Estimation of the quantity of stimulating paste applied on Heveas according to their circumference in the south-east of the Ivory Coast. African Agronomy, 1, 25-32. 
[14] Taussky H. H. and Shorr E. (1953) A micro colorimetric method for the determination of inorganic phosphorus. J. Biol. Chem., 202, 675-685.

[15] Boyne A. F. and Ellman G. L. (1972) A methodology for analysis of tissue sulphydryl components. Anal. Biochem., 46, $639-653$

[16] Obouayeba S. and Soumahin E. F. (2013) Improvement of the productivity of the rubber tree in reverse bleeding. Progress report, FIRCA-CNRA PROJECT, June 2010, 12p.

[17] Gohet E. (1996) Latex production by Hevea brasiliensis. Relationship with growth. Influence of different factors: clonal origin, hormonal stimulation, hydrocarbon reserves. Thesis (PhD). University Sci. Tech. Montpellier II, France, $343 \mathrm{pp}$.

[18] Adou C. Y. B., Atsin O. J. G., Essehi J. L., Ballo K. E., Soumahin F. E., Obouayeba P. A., \& Obouayeba, S. (2018). Latex micro diagnosis, modern management tool of rubber plantations of clones with moderate metabolism GT 1, RRIC 100 and BPM 24. Journal of Applied Biosciences, 121, 1209812109.

[19] An F., Rookes J., Xie G., Cahill D., Cai X., Zou Z., \& Kong L. (2016). Ethephon increases rubber tree latex yield by regulating aquaporins and alleviating the tapping-induced local increase in latex total solid content. Journal of plant growth regulation, 35(3), 701-709.
[20] Eschbach J. M. (1986) Clone GT 1. Possibility of reducing the bleeding frequency. Rev. Gen. Caout. Plast. 659, 165-168.

[21] Eschbach J. M and Tonnelier M. (1984) "Influence of the method of stimulation, the concentration of the stimulant and the frequency of its application on the production of the GT 1 clone in Côte d'Ivoire", In: C. R. Coll. Expl. Physiol. Amel. Hévéa, IRCA-CIRAD, ed, Montpellier, France, 295-306, 1984.

[22] Jacob J. L.; Serres E.; Prevot J. C.; Lacrotte R.; ClementVidal, A.; Eschbach J. M. and D'Auzac J. (1988) Development of latex diagnosis. Agritrop, 12(2), 97-118.

[23] Obouayeba S.; Boa D.; Gohet E.; Dian K.; Ouattara N. and Kéli J. (2000) Dynamics of vegetative growth of Hevea brasiliensis in determining tapping norms. J. Rubb. Res. 3(1), 53-62.

[24] Jacob J. L.; Prevot J. C.; Lacrotte R., Eschbach, J. M. (1995) Latex diagnosis. Planting, Research, Development. 2, 34-37.

[25] Commère J. and Eschbach J. M. (1988). The advantage of low intensity upward tapping in Côte d'Ivoire. C. R. Coll. Expl. Physiol. Amél. Hevea, J. L. Jacob et J. C Prevot; eds., IRCACIRAD, Montpellier, France, $283-290$.

[26] Tupy J. and Primot L. (1976) Control of carbohydrate metabolism by ethylene in latex vessels of Hevea brasiliensis Müll, Arg. In relation to rubber production. Biol. Plant., 18, 373-384. 